\title{
Pengaruh Video Pembelajaran Gerak dan Lagu untuk Meningkatkan Fisik Motorik pada Anak Usia Dini
}

\author{
Farida Mayar1, Riri Sakti ${ }^{\llbracket}$, Lisfa Yanti ${ }^{1}$, Betti Erlina ${ }^{1}$, Osriyenti ${ }^{1}$, Warni Holiza ${ }^{1}$ \\ Pendidikan Anak Usia Dini, Universitas Negeri Padang, Indonesia(1) \\ DOI: $\underline{10.31004 / o b s e s i . v 6 i 4.2081}$
}

\begin{abstract}
Abstrak
Permasalahan yang ditemukan di lapangan yaitu kegiatan gerak dan lagu masih menggunakan lagu orang dewasa belum sesuai dengan tema pembelajaran contohnya lagu Mahumere anak-anak tetap mengikuti gerakan namun lagu tidak sesuai dengan anak usia dini. Tujuan penelitian ini adalah untuk mengetahui pengaruh video pembelajaran gerak dan lagu untuk meningkatkan fisik motorik pada anak usia dini. Metode yang digunakan adalah metode eksperimen dengan desain penelitian tipe one group pretest-postest design. Hasil penelitian yang dilakukan terhadap 10 anak pada pertemuan 1 dan 2, dapat diketahui bahwa keterampilan motorik anak mengalami peningkatan $17,56 \%$ pada pra-intervensi diperoleh rata-rata 50,25\% dan pada pertemuan pertama menjadi $67,81 \%$. Pada pertemuan 2 keterampilan motorik anak semakin mengalami peningkatan sebesar 19\%, dimana pada pertemuan kedua anak memperoleh rata-rata $86,81 \%$.
\end{abstract}

Kata Kunci: video; pembelajaran gerak dan lagu; fisik motorik; anak usia dini

\begin{abstract}
The problems found in the field are that movement activities and songs still use adult songs that are not in accordance with the learning theme, for example, the mahumere song, children still follow the movement, but the song is not suitable for early childhood. The purpose of this study was to determine the effect of motion learning videos and songs to improve physical motor skills in early childhood. The method used is an experimental method with a one group pretest-posttest type of research design. The results of research conducted on 10 children at meetings 1 and 2, it can be seen that the motor skills of children have increased by $17.56 \%$ in the pre-intervention obtained an average of $50.25 \%$ and at the first meeting to $67.81 \%$. At the second meeting the children's motor skills increased by $19 \%$, where at the second meeting the children obtained an average of $86.81 \%$
\end{abstract}

Keywords: videos; movement and song learning; motor physics; early childhood.

Copyright (c) 2022 Farida Mayar, et al.

$\triangle$ Corresponding author : Riri Sakti

Email Address : ririsakti01@gmail.com (Padang, Sumatera Barat, Indonesia)

Received 15 September 2021, Accepted 23 January 2022, Published 26 January 2022 


\section{PENDAHULUAN}

Anak usia dini merupakan bagian paling penting dari kehidupan di Indonesia, dapat dilihat dalam hal mengadopsi nilai-nilai yang dibutuhkan anak-anak. Masa usia dini merupakan masa pertumbuhan dan perkembangan sangat pesat atau lebih dikenal dengan masa keemasan atau sering disebut dengan golden age. Di usia ini anak memiliki masa tumbuh kembang di mana terjadi perkembangan dari berbagai aspek dini seperti perkembangan kognitif, sosial-emosional, agama moral, bahasa, fisik-motorik dan psikologi. Perkembangan tersebut menjadikan proses belajar bagi anak. Anak memiliki rasa ingin tahu yang sangat tinggi, salah satunya keingintahuannya tentang seks. Anak ingin mengetahui tentang tubuhnya sendiri, mengetahui fungsi-fungsi organ tubuhnya dan juga perbedaan-perbedaan dengan milik orang lain (Monica \& Yaswinda, 2021).

Periode ini merupakan tahap tercepat dalam hal perkembangan mereka, di mana kepribadian mereka dibangun, mereka sangat dipengaruhi oleh lingkungan terdekat mereka dan terbuka untuk segala jenis pembelajaran (Latiana et al., 2018). Kualitas pengalaman yang diperoleh anak di masa usia dini akan memjadikan lebih bermakna untuk mencapai masa depanya. Secara alami anak anak adalah pembelajar yang aktif. Mereka sangat menyenangi melakukan pengamatan, eksplorasi, berimajinasi, menemukan, melakukan penyelidikan, mengumpulkan informasi serta berbagi pengalaman. Pengalaman belajar pada masa usia dini dapat dapat ditingkatkan kepada yang lebih tinggi melalui kepedulian orang tua, guru pada anak, agar anak dapat ditingkatkan supaya terbentuk sikap positif terhadap belajar (Mollborn et al., 2018).

Pembelajaran merupakan proses ilmiah. Karena itu Kurikulum 2013 mengamanatkan esensi pendekatan ilmiah dalam pembelajaran. Pendekatan ilmiah diyakini sebagai titian emas perkembangan dan pengembangan sikap, keterampilan, dan pengetahuan anak didik (Aini et al., 2021). Perkembangan pada usia dini mencakup perkembangan fisik dan motorik, kognitif, sosial emosional dan bahasa menurut Suryana, (2018) merupakan masa pertumbuhan yang paling hebat dan sekaligus paling sibuk. Pada masa ini anak sudah memiliki keterampilan dan kemampuan meskipun belum sempurna. Perkembangan fisik motorik anak akan lebih terobtimalkan jika lingkungan mendukung untuk bergerak, perkembangan fisik morik dapat dikembangkan melalui kegiatan seni yaitu melalui lagu, lagu di sebutkan oleh (Mutiah, 2015).

Gerak dan lagu akan menjadi sangat kreatif jika di padukan bersamaan, gerak dan lagu dalam pelaksanaan pembelajaran dapat dipadukan dengan bidang-bidang lain, dengan kata lain bahwa konsep pembelajaran gerak dan lagu merupakan kegiatan yang sangat mudah untuk diterapkan, simple, bisa mengembangkan aspek pembelajaran serta mengembangkan kemampuan anak.

Pembelajaran gerak dan lagu merupakan pembelajaran di mana anak diberikan materi pembelajaran melalui gerak dan lagu. Gerak dan lagu yang dipakai dapat berupa gerak yang mengembangkan fisik motorik sesuai dengan lagu, misalnya lagu menanam jagung anak diajak untuk bergerak sesuai gerakan. Akan tetapi gerak dan lagu ini diberikan untuk mempermudah anak dalam menerima pembelajaran terutama untuk perkembangan fisik dan motorik anak.

Pembelajaran gerak dan lagu biasanya menimbulkan kesan bermakna bagi anak, anak akan lebih mudah mengingat materi pembelajaran yang diberikan oleh guru. Kebermaknaan pembelajaran gerak dan lagu akan memberikan dampak positif yaitu mengembangkan kecerdasan pada anak (Respati et al., 2018). Kegiatan gerak dan lagu pada umumnya di sukai anak usia dini kenyataannya di lapangan tidak semua pembelajaran gerak dan lagu sesuai dengan tema pembelajaran yang sudah di tetapkan oleh sekolah, biasanya semua kegiatan pembelajaran gerak dan lagu di ambil guru dari lagu yang sudah ada padahal tidak sesuai dengan tema pembelajaran contohnya : lagu balon ku sementara hari itu tema pembelajarannya keluargaku. 
Permasalahan kedua untuk kegiatan gerek dan lagu masih menggunakan lagu orang dewasa belum sesuai dengan tema pembelajaran contohnya lagu mahumere anak-anak tetap mengikuti gerakan namun lagu tidak sesuai dengan anak usia dini dengan kenyataan di lapangan saya menciptakan gerak dan lagu untuk peningkatan fisik motorik anak usia dini, anak tetap bergerak dengan melihat gerak yang di contohkan oleh guru, gerak dan lagu yang didengar oleh anak belum menunjang untuk pembelajaran yang bermakna. Lagu model yang dikembangkan oleh Purwanto, (2011) digunakan untuk mengembangkan karakter anak usia dini, untuk itu perlu ada gerak dan lagu untuk mengembangkan fisik motorik anak usia dini.

Hakikat pendidikan anak usia dini adalah periode pendidikan yang sangat menentukan perkembangan dan arah masa depan seorang anak sebab pendidikan yang dimulai dari usia dini akan membekas dengan baik jika pada masa perkembangannya dilalui dengan suasana yang baik, harmonis, serasi, dan menyenangkan (Assagaf, 2020). Anak akan belajar dengan baik dan bermakna bila anak merasa nyaman secara psikologis serta kebutuhan fisiknya terpenuhi, anak mengkonstruksi pengetahuannya, anak belajar melalui interaksi sosial dengan orang dewasa dan anak lainnya, eksplorasi, pencarian, penggunaaan, belajar melalui bermain, unsur perbedaan anak diperhatikan (Movitaria, 2017). tujuan pendidikan anak usia dini, yaitu menyiapkan anak untuk berkembanga secara komprehensif, sudah barang tentu orientasi pendidikan pada anak usia dini tidak hanya terbatas pada aspek pengembangan kecerdasan semata, tetapi juga mencakup aspek perkembangan yang lebih luas. Aspek-aspek perkembangan yang terjadi pada anak usia dini meliputi: aspek fisik dan motorik, aspek kognitif, aspek bahasa, aspek moral dan nilai-nilai agama, aspek sosioemosional, aspek seni dan kreativitas (Yenti \& Maswal, 2021).

Compact disc digital video pembelajaran merupakan bentuk dari multimedia yang di dalamnya terdapat konten materi pembelajaran yang disajikan berupa audio, video, grafik, teks, animasi, menjadi satu kesatuan sinergis dan simbiosis yang menghasilkan manfaat yang lebih bagi pengguna (Santosa, 2014). Pembelajaran yaitu menciptakan bahan ajar yang tepat guna sesuai dengan kebutuhan. Dalam kaitannya dengan pengembangan produk multimedia pembelajaran pembelajaran adalah untuk memfasilitasi dan meningkatkan kinerja guru dalam proses pembelajaran (Movitaria \& Shandra, 2020).

Seiring dengan pesatnya perkembangan media informasi dan komunikasi, baik perangkat keras (hardware) maupun perangkat lunak (software), akan membawa perubahan bergesernya peranan guru, termasuk guru Taman kanak - kanak sebagai penyampai pesan atau informasi. manfaat Compact disc digital video adalah untuk memudahkan guru dalam menyampaikan pembelajaran dan memanfaatkan teknologi tepat guna sehingga pembelajaran menjadi lebih menarik.

Pembelajaran gerak dan lagu diadaptasi dari model pembelajaran musik yang dikembangkan oleh Dalcroze yaitu menyadari bahwa gerak dan lagu dapat memberikan manfaat positif bagi anak. Pada dasarnya gerak dan lagu merupakan kegiatan yang sarat akan makna bermain sambil belajar, belajar seraya bermain.

Hal ini sejalan dengan pendapat Yusanti \& Rakimahwati, (2019) bahwa aktivitas pembelajaran melalui gerak dan lagu akan menyenangkan anak sekaligus menyentuh perkembangan bahasa, kepekaan akan irama musik, perkembangan motorik, rasa percaya diri, serta keberanian mengambil resiko. Gerak dan lagu akan menjadi sangat kreatif jika di padukan bersamaan, gerak dan lagu dalam pelaksanaan pembelajaran dapat dipadukan dengan bidang-bidang lain, dengan kata lain bahwa konsep pembelajaran gerak dan lagu merupakan kegiatan yang sangat mudah untuk diterapkan, simple, bisa mengembangkan aspek pembelajaran serta mengembangkan kemampuan anak.

Pembelajaran gerak dan lagu merupakan pembelajaran di mana anak diberikan materi pembelajaran melalui gerak dan lagu. Gerak dan lagu yang dipakai dapat berupa lagu dan gerakan, misalnya lagu menanam jagung anak diajak untuk bergerak sesuai lagu. Gerak dan lagu ini diberikan untuk mempermudah anak dalam menerima pembelajaran. Tujuan utama penggunaan gerak dan lagu dalam pembelajaran bukanlah penguasaan gerak dan lagunya, 
tetapi gerak dan lagu sebagai alat atau media untuk mempelajari aspek materi yang diinginkan. Gerak dan lagu digunakan dalam pembelajaran untuk meningkatkan fisik motorik anak.

\section{METODOLOGI}

Jenis Penelitian yang digunakan dalam penelitian ini adalah metode eksperimen, metode eksperimen adalah sebagai metode penelitian yang digunakan untuk mencari pengaruh perlakuan tertentu terhadap yang lain dalam kondisi yang terkendalikan (Sugiyono, 2011). Desain penelitian yang digunakan adalah pre-ekperimen yaitu dengan tipe one group pretest-postest design. Pada penelitian ini awalnya peneliti melakukan pengukuran terhadap variabel terikat sebelum diberi tindakan, baru setelah itu diberi perlakuan, kemudian dilakukan pengukuran kembali terhadap variabel terikat dengan alat ukur yang sama. Selengkapnya dapat digambarkan pada gambar 1.

\section{Pretest $(\mathrm{O} 1) \longrightarrow$ Perlakuan $(\mathrm{x}) \longrightarrow$ Postest $(\mathrm{O} 2)$}

\section{Gambar 1. Desain one group pretest-postest design}

Adapun objek yang dijadikan populasi adalah anak di TK Tunas harapan, yang berjumlah adalah 30 orang. Sampel dalam penelitian ini terdiri dari 15 orang siswa. Teknik pengumpulan data dengan menggunakan observasi (pengamatan) dan dokumentasi. teknik analisis data dilakukan dengan cara membandingkan hasil rerata pretest dan posttest kelompok eksperimen dengan cara menguji statistik uji-t.

\section{HASIL DAN PEMBAHASAN}

Hasil penelitian pengembangan motorik halus anak melalui gerak dan lagu ini menunjukkan bahwa keterampilan motorik meningkat dari tiap pertemuannya. Tabel 1 adalah data observasi sebelum penelitian.

Tabel 1. Format Tabel

\begin{tabular}{crrr}
\hline Responden & Skor & Persentase & Keterangan \\
\hline AP & 32,5 & $40,62 \%$ & Belum Mencapai Target \\
CA & 34 & $42,50 \%$ & Belum Mencapai Target \\
DP & 46,5 & $58,12 \%$ & Belum Mencapai Target \\
FA & 36,5 & $45,62 \%$ & Belum Mencapai Target \\
KP & 40 & $50,00 \%$ & Belum Mencapai Target \\
KA & 45,5 & $56,87 \%$ & Belum Mencapai Target \\
MR & 39 & $48,75 \%$ & Belum Mencapai Target \\
MA & 45,5 & $56,87 \%$ & Belum Mencapai Target \\
MR & 39,5 & $49,37 \%$ & Belum Mencapai Target \\
RM & 43 & $53,75 \%$ & Belum Mencapai Target \\
\hline Rata-rata kelas & 40,2 & $50,25 \%$ & Belum Mencapai Target \\
\hline
\end{tabular}

Dari tabel 1 menunjukkan bahwa rata-rata kelas memiliki skor keterampilan motorik halus anak 40,2 atau 50,25\%. Hasil pengamatan pada 10 anak menunjukkan bahwa keterampilan motorik anak masih di kategori belum mencapai target yang telah ditentukan yaitu $70 \%$. Skor terendah diperoleh oleh AP yaitu 32,5 atau 40,62\% dan skor tertinggi diperoleh oleh DP yaitu 46,5 atau 58,12\%. Data keterampilan motorik anak pra-penelitian masih dalam kategori mulai muncul dan belum mencapai target. Setiap harinya anak diminta untuk melaksanakan tugas yang diberikan guru, serta berdasarkan hasil pengamatan anak terlihat bosan atau tidak tertarik saat pembelajaran diberikan guru. 
Data keterampilan motorik anak pertemuan 1 menunjukkan ada empat anak sudah memenuhi kategori keberhasilan dan enam anak belum mencapai target walaupun sudah mengalami peningkatan. Hasil pengamatan terjadi karena anak masih beradaptasi dengan kegiatan gerak dan lagu, gaya belajar dan kecerdasan anak yang berbeda-beda, dan faktor lainnya (keturunan/bawaan, minat, lingkungan, dan kematangan).

Pada pertemuan kedua perlunya tindakan guru merancang kegiatan dengan tema dan gerakan yang disesuaikan dengan usia anak yaitu (1) Anak-anak diberikan kegiatan secara bersama-sama sesuai dengan yang terjadwal (2) Guru mencontohkan gerakan dengan lagu yang bersemangat, (3) Anak-anak melakukan gerakan diawali dengan gerakan yang mudah dan sederhana, (4) Guru memberikan contoh gerakan yang sering terlihat oleh anak, (5) Guru dan anak melakukan gerakan diiringi lagu yang bersemangat, (6) Guru selalu memotivasi anak di kegiatan pemebalajaran gerak dan lagu.

Berdasarkan hasil pengamatan pertemuan pertama menunjukkan adanya peningkatan keterampilan motorik anak dari 50,25\% menjadi $67,81 \%$ yaitu sebesar $17,56 \%$. Namun kesepakatan peneliti dan kolaborator untuk keberhasilan tindakan yaitu sesbesar $70 \%$ dan dilanjutkan ke pertemuan kedua. Hasil pengamatan pada 10 anak menunjukkan bahwa keterampilan motorik anak meningkat dan mencapai target yang telah ditentukan yaitu $70 \%$.

Data 10 anak diketahui bahwa keterampilan motorik anak mengalami peningkatan. Pada tahap pra intervensi diperoleh peningkatan sebesar $17,56 \%$ dari $50,25 \%$ menjadi $67,81 \%$. Pada pertemuan kedua keterampilan motorik anak semakin mengalami peningkatan sebesar $19 \%$, menjadi 86,81\%. Hasil penelitian menunjukkan bahwa pengaruh video dapat meningkatkan keterampilan motorik anak dalam kegiatan pembelajaran gerak dan lagu.

Berdasarkan hasil observasi, wawancara, dan dokumentasi pada penelitian ini terlihat perbandingan seberapa jauh peningkatan keterampilan motorik anak pada kondisi awal sebelum kegiatan pembelajaran gerak dan lagu dan kondisi akhir setelah kegiatan yang menunjukkan bahwa adanya peningkatan keterampilan motorik anak. Sesuai dengan penelitian yag dilakukan oleh Tejapermana \& Asmira, (2018) yang mengutarakan bahwa model pembelajaran gerak dan lagu dapat meningkatkan aspek-aspek perkembangan anak dan berkaitan dengan guru dalam mengelola pembelajaran yang menyenangkan. Pembelajaran gerak dan lagu dapat mengoptimalkan motorik anak sesuai dengan usia dan tahapan perkembangan. Hasil penelitian yang sama dengan (Sudjono \& Kusumastuti, 2017) bahwa pembelajaran gerak dan lagu dapat berupa kegiatan bernyanyi sambil bergerak berdasarkan irama musik dan lagu dengan melakukan inovasi pada pembelajaran untuk meningkatkan motorik kasar anak. Pendidikan anak usia dini ditujukan untuk meningkatkan aspek- aspek perkembangan anak yang sangat berkaitan dengan kemampuan guru dalam mengelola pembelajaran (Fauziddin \& Mufarizuddin, 2018). Anak-anak sangat dekat dengan permainan (Nurhayani et al., 2022). Dalam kehidupan sehari-hari, permainan baik tradisional maupun modern selalu dilakukan anak-anak. Permainan yang dilakukan merupakan sesuatu yang dianggap wajib dilakukan sebagai sarana untuk perkembangan fisik motorik bagi Anak Usia Dini. Pembelajaran dengan bermain sangat membantu anak dalam melaraskan koordinasi dengan angota tubuh anak di setiap gerakan anak (Respati et al., 2018).

Pembelajaran gerak dan lagu yang dilakukannya tidaklah sulit dan sederhana sekali, musik iringan yang menggambarkan kesenangan atau kegembiraan anak untuk bergerak dan memberikan contoh-contoh gerakan. Strategi pembelajaran melalui gerak dan lagu ini menggunakan media yaitu video yang sesuai dengan ritme dan karakteristik anak usia dini. Gerak dan lagu merupakan kegiatan yang melibatkan seluruh tubuh dan panca indera anak (Prahesti et al., 2019). Dengan demikian kemampuan guru dalam mengelola pembelajaran, menciptakan kondisi yang menyenangkan dalam kegiatan pembelajaran, serta peserta didik yang mampu mengikuti jalannya pembelajaran sehingga perkembangan motorik anak meningkat sesuai dengan usia dan tahapan perkembangan anak (Rupnidah et al., 2022). 
Temuan penelitian sebelumnya mengenai video pembelajaran juga menyatakan bahwa video dapat meningkatkan semangat siswa (Apriansyah, 2020; Wuryanti \& Kartowagiran, 2016). Temuan penelitian lain juga menyatakan media video binatang dapat berpengaruh terhadap perkembangan motorik kasar anak (Nurdin et al., 2019; Ponza et al., 2018).

\section{SIMPULAN}

Berdasarkan data hasil penelitian yang telah dilakukan terhadap 10 anak pada pertemuan 1 dan 2, dapat diketahui bahwa keterampilan motorik anak mengalami peningkatan $17,56 \%$ pada pra-intervensi diperoleh rata-rata $50,25 \%$ dan pada pertemuan pertama menjadi $67,81 \%$. Pada pertemuan 2 keterampilan motorik anak semakin mengalami peningkatan sebesar $19 \%$, dimana pada pertemuan kedua anak memperoleh rata-rata $86,81 \%$. Pembelajaran dengan gerak dan lagu memberikan kesempatan bagi anak untuk bereksplorasi dengan sumber dan media pembelajaran yang bervariasi serta memberikan kesempatan bagi anak untuk memperoleh pengetahuan secara mendalam tentang sesuatu hal. Keterampilan motorik anak yang ditunjukkan oleh anak selama diberikan tindakan penelitian terlihat dari berbagai karakteristik antara lain mengkoordinasi mata dan tangan untuk melakukan gerakan, ketepatan dan ketelitian rangsangan sensori motor, menirukan gerakan manipulatif, serta mengekspresikan diri.

\section{UCAPAN TERIMA KASIH}

Peneliti mengucapkan terimakasih banyak kepada Kepala Sekolah dan Guru TK Tunas harapan atas kerjasama yang baik selama penelitian ini dilakukan. Peneliti juga ucapkan terimakasih kepada editor dan reviwer jurnal yang telah memperbaiki artikel ini menjadi lebih baik.

\section{DAFTAR PUSTAKA}

Aini, F., Efendi, Y., \& Movitaria, M. A. (2021). Peningkatan Aktivitas Dan Hasil Belajar PAIDBP Siswa Kelas IV Sekolah Dasar Melalui Penggunaan Model Discovery Learning. Attadrib: Jurnal Pendidikan Guru Madrasah Ibtidaiyah, 4(2), 55-61. https://doi.org/10.54069/attadrib.v4i2.145

Apriansyah, M. R. (2020). Pengembangan Media Pembelajaran Video Berbasis Animasi Mata Kuliah Ilmu Bahan Bangunan Di Program Studi Pendidikan Teknik Bangunan Fakultas Teknik Universitas Negeri Jakarta. Jurnal Pensil: Pendidikan Teknik Sipil, 9(1), 9-18. https://doi.org/10.21009/ipensil.v9i1.12905

Assagaf, L. (2020). Penerapan Supervisi Akademik di PAUD. Jurnal Al-Hikmah, 1(1).

Fauziddin, M., \& Mufarizuddin, M. (2018). Useful of clap hand games for optimalize cogtivite aspects in early childhood education. Jurnal Obsesi: Jurnal Pendidikan Anak Usia Dini, 2(2), 162-169. https:// doi.org/10.31004/obsesi.v2i2.76

Latiana, L., Samsudi, S., Sugiyo, S., \& Slameto, S. (2018). Developing Collaboration-Based Supervision Model to Enhance the Professionalism of Early Childhood Education Teachers. The Journal of Educational Development, 6(1), 132-143.

Mollborn, S., Lawrence, E., \& Root, E. D. (2018). Residential mobility across early childhood and children's kindergarten readiness. Demography, 55(2), 485-510. https://doi.org/10.1007/s13524-018-0652-0

Monica, M. A., \& Yaswinda, Y. (2021). Analisis Implementasi Kurikulum 2013 PAUD di Masa Pandemi Covid-19 di Indonesia. Jurnal Basicedu, 5(2), 643-653. https://doi.org/10.31004/basicedu.v5i2.781

Movitaria, M. A. (2017). Pengaruh Penerapan Pembelajaran Brain Based Learning Approach dan Motivasi Terhadap Hasil Belajar IPA Siswa Kelas V Gugus IV Kecamatan Padang Utara. Universitas Negeri Padang. 
Movitaria, M. A., \& Shandra, Y. (2020). Improving Teachers' Abilities In Video Based Learning By Using Microsoft Powerpoint Application Through Workshop. Jurnal Basicedu, 4(4), 14231428. https://doi.org/10.31004/basicedu.v4i4.557

Mutiah, D. (2015). Psikologi bermain anak usia dini. Kencana.

Nurdin, E., Ma'aruf, A., Amir, Z., Risnawati, R., Noviarni, N., \& Azmi, M. P. (2019). Pemanfaatan video pembelajaran berbasis Geogebra untuk meningkatkan kemampuan pemahaman konsep matematis siswa SMK. Jurnal Riset Pendidikan Matematika, 6(1), 87-98. https://doi.org/10.21831/jrpm.v6i1.18421

Nurhayani, N., Yaswinda, Y., \& Movitaria, M. A. (2022). Model Evaluasi Cipp Dalam Mengevaluasi Program Pendidikan Karakter Sebagai Fungsi Pendidikan. Jurnal Inovasi Penelitian, 2(8), 2353-2362.

Ponza, P. J. R., Jampel, I. N., \& Sudarma, I. K. (2018). Pengembangan Media Video Animasi pada Pembelajaran Siswa Kelas IV di Sekolah Dasar. Jurnal Edutech Undiksha.

Prahesti, S. I., Taulany, H., \& Dewi, N. K. (2019). Gerak dan Lagu Neurokinestetik (GELATIK) untuk Menumbuhkan Kreativitas Seni Anak Usia Dini. Jurnal Obsesi: Jurnal Pendidikan Anak Usia Dini, 4(1), 162-171. https://doi.org/10.31004/obsesi.v4i1.289

Purwanto, S. (2011). Pengembangan lagu model sebagai media pendidikan karakter bagi anak usia dini. In Yogyakarta: Tesis Pascasarjana UIN Sunan Kalijaga.

Respati, R., Nur, L., \& Rahman, T. (2018). Gerak dan Lagu Sebagai Model Stimulasi Pengembangan Kecerdasan Kinestetik Anak Usia Dini. Jurnal Pendidikan Usia Dini, 12(2), 321-330. https://doi.org/10.21009/JPUD.122.13

Rupnidah, R., Yaswinda, Y., \& Movitaria, M. A. (2022). Evaluasi Pelaksanaan Program Holistik Integratif Di Tk Al-Huffazh Payakumbuh. Jurnal Inovasi Penelitian, 2(8), 2373-2380.

Santosa, A. B. (2014). Keefektifan Pembelajaran Mengunakan Media CD Pembelajaran Pada Mata Pelajaran IPS Kelas V S. 1(1), 19-37.

Sudjono, E. T. K., \& Kusumastuti, E. (2017). Proses Pembelajaran Gerak dan Lagu yang Kreatif Berdasarkan Kurikulum 2013 di TK Miryam Semarang. Jurnal Seni Tari, 6(2).

Sugiyono. (2011). Metode Penelitian Pendidikan ( Pendekatan. Kuantitatif, Kualitatif, dan R\&D). Alfabeta.

Suryana, D. (2018). Pendidikan Anak Usia Dini: Stimulasi dan Aspek Perkembangan Anak (Pertama). Prenadamedia Group. http://repository.unp.ac.id/21033/1/STIMULASI ASPEK PERKEMBANGAN ok.pdf

Tejapermana, P. T., \& Asmira, Y. D. (2018). Pengembangan Model Gerak dan Lagu Berbasis Budaya Lampung Untuk Guru PAUD Di Bandar Lampung. Al-Athfaal: Jurnal Ilmiah Pendidikan Anak Usia Dini, 1(1), 18-33. https:// doi.org/10.24042/ajipaud.v1i1.2999

Wuryanti, U., \& Kartowagiran, B. (2016). Pengembangan media video animasi untuk meningkatkan motivasi belajar dan karakter kerja keras siswa sekolah dasar. Jurnal Pendidikan Karakter, 6(2). https:// doi.org/10.21831/jpk.v6i2.12055

Yenti, Y., \& Maswal, A. (2021). Pentingnya Peran Pendidik dalam Menstimulasi Perkembangan Karakter Anak di PAUD. Jurnal Pendidikan Tambusai, 5(1), 2045-2051.

Yusanti, A., \& Rakimahwati, R. (2019). Development of Compact Disc Motion and Song Learning to Improve the Physical of Early Children. Journal of Nonformal Education, 5(2), 183-188. 